\title{
The Influence of Parents' Involvement on Children with Special Needs' Motivation and Learning Achievement
}

\author{
Siti Bariroh ${ }^{1}$ \\ ${ }^{1}$ Educational Administration Department, Faculty of Teacher Training and Education, University of Gresik, \\ Indonesia \\ Correspondence: Siti Bariroh, Educational Administration Department, Faculty of Teacher Training and \\ Education, University of Gresik, Jl. Arief Rahman Hakim 2B, Gresik, Indonesia. Tel: 62-813-3093-4849. E-mail: \\ sitibariroh60@gmail.com
}

Received: December 6, 2017

Accepted: January 10, 2018 Online Published: March 28, 2018

doi:10.5539/ies.v11n4p96

URL: https://doi.org/10.5539/ies.v11n4p96

\begin{abstract}
Some of the abnormal children face burden, distraction, interruption, tardiness, or risk factors so that they cannot get an optimum growth without special treatment or intervention. This study was aimed at discovering the influence of parents' involvement to the learning motivation and achievement of children with different abilities. This research is a regressive model. The population was children with different abilities in SMP Negeri 4 Gresik, East Java Indonesia. The data collected through questionnaire and documentation, were then analyzed using linear regression test. The $t$-test results showed $t_{\text {calculate }}$ value for variables of parents' involvement (X) was 3,813 . The results showed that $t_{\text {calculate }}>t_{\text {table }}$ or 3,813>2,093 or $t$ value is higher than $t$ table. It means that parents' involvement sigifcantly influences children's motivation. The result of the $t$-test also indicated that $t_{\text {calculate }}$ value for parents' involvement $(\mathrm{X})$ was 3,601. If compared to $t_{\text {table, }}$, then, $t_{\text {calculate }}>t_{\text {table }}$ or $3,601>2,093$. It means that there is an influence of parents' involvement on children's achievement as well. Based on the finding, it can be recommended that parents should be more intensive in assisting, accompanying, and guiding their children, especially especially to the children who have special needs so that their motivation and academic achievement can be enhanced. It is also recommended that teachers and school should give more fruitful collaboration between schools to facilitate their needs and potentials.
\end{abstract}

Keywords: parents' involvement, motivation, learning achievement, children with special needs

\section{Introduction}

Human development happens continuously or simultaneously. Success in reaching the stage of development will determine the success in the following stage. If the process of development is hampered and disrupted it would be difficult to achieve optimal development and growth. This suggests conceptually that children with special needs have broader meanings and spectrums than the concept of exceptional, disabled, or disadvantaged children. Children with different abilities not only include children who have special needs that are permanent due to certain disabilities, but also children with temporary different abilities. Children with temporary different abilities are called risk factors such as individuals who have problems in their development that may be affected by their future learning abilities, or having vulnerabilities, weakness or high risks on the appearance of obstacles or disorders in learning or in the following development.

Children with "special needs" or better known as children with different abilities refer to the children who experienced obstacles in the development of his behavior. According to Handoyo (2001), "behavior is all actions of an individual, smaller, or greater, that can be seen, heard, and perceived by the sense of taste in the skin, and (not in the heart) by others or selves". Therefore, behavior includes speech or voice, movements or actions either in the form of irregular or irregular movements, intended or unintended, intentionally or unintentionally, and useful or useless. The behavioral development of children with special needs will cause barriers in a certain aspect. Because the two types of behavior are required in social communication. Then, learning process of these children will be obstructed if they are not cared and treated properly.

Based on the above background, the research questions are formulated as follows:

1) Does the parents' involvement influence motivation of the children who have special needs in SMP Negeri 4 


\section{Gresik?}

2) Does the parents' involvement influence learning achievement of the children with special needs in SMP Negeri 4 Gresik?

3) Does the parents' involvement influence motivation and achievement of the children with secial needs in SMP Negeri 4 Gresik?

The objectives of this study are aimed to address the following points, namey:

1) Understand the influence of parents' involvement on achievement motivation of the children with special needs in SMP Negeri 4 Gresik.

2) Undersatnd the influence of parents' involvement on the learning achievement of the children with special needs in SMP Negeri 4 Gresik.

3) Understand the influence of parents' involvement on the achievement motivation and learning achievement of the children with special needs in SMP Negeri 4 Gresik.

\section{Literature Review}

\subsection{Parents' Involvement}

The emergence of various disorders or developmental barriers in individuals with special needs is a phenomenon that needs to be addressed further so that they can still live a good life and optimize any ability they possess, no matter how small it is. Several studies indicate that the topic of children with special needs is rarely discussed as it is vague to discuss. Hadjiyiannakou, Ioannou, and Tzoigkouros (2007) propose several reasons for that. First, when parents have disabled children, the identities of the family also changed, the feeling of insecurity is spread among their lives. Second, parents have a negative energy and image and they are very depressed because of the existence of the disabled child in their family. Third, parents have no choice, and they feel insecure, the road of their life is too difficult. Fourth, parents are correlated with failure, they feel embarrassed and insecure and sometimes they seemed that they have a grief.

This is important because regardless of its limitations, every human being has the same right to grow, develop, accept, and perform their role in society. According to Mintari and Widyarini (2015), they say that one of the idea to be owned by parents who have the disabled children is that by seeking social support for emotional reasons. They said that this idea can be used to avoid having negative thinking for parents with disabled children. Furthermore, Faradina (2016) explains that positive parents' acceptance toward disabled children will lead to the positive development.

The efforts to optimize the development of adolescents with special needs is none other than to provide education and training needed, both related to the ability of daily life, academic materials, and work skills. Related to this matter, the process of education program for children with special needs emphasizes on the efforts to guide the students to be able to live their life independently, by optimizing the ability of the senses or parts of certain parts of themselves that still can be operated. Next, to achieve the maximum results, every educational process requires the cooperation between the school and the parents. According to Buchori (2006), education shall fail without parents' participation. One of the main conditions parents must fulfill in seeking good cooperation with the school so that the education process is optimal is to give full attention to the child's growth as a person, and not just the attention to what the child has achieved. There are some supporting ideas about the parents-involvement in the school deals the students with disabilities. (Rodriguez, Blatz, \& Elbaum, 2014)explain that the school staff, including teachers, not only communicated with the parents about students' progress but also frequently mentioned that the teachers were accessible. There was a room to communicate, it is called Individualized Education Program (IEP) meeting, the result explain that the parents' involvements bring the child's progress and allow the parents a variety of communication methods. In a similar sense, Clough and Nutbrown (2004) say that the parents should be included in the school because information about processes, system and intervention in the school are needed by parents; the responsibility for the care is important, and fundamentally, more time and the most intimate knowledge are parents' responsibility (Whitning, 2012).

MacKichan and Harkins (2013) explain that when we are discussing about the inclusive education or students with the special need that they access the curriculum through adapted or individualistic plan. Moreover, parental involvement in developing the individualistic plan or Individual Program Planning (IIP) in Canada is pertinent to success of both the children's education and the plan as well. Meanwhile, Wang (2009) writes that it must be carefully considered to place special need students in mainstream school by concerning all the participants such as teachers, parents, school administrators, students, as well as the society at large, without all fully participating in 
the process, a less than optimal outcome for the special needs student may occur resulting in lower academic achievement.

In line with MacKichan and Harkins (2013), Murray, Handyside, Straka, and Arton-Titus (2013), Rodriguez et al. (2014), Whitning (2012) also explain that parents have to be respect, understand, and value their children in the educational decision-making process for their child with disabilities to optimize their potentials. Both parents and professional, teachers, could benefit from increased interactions and education on how to create successful partnership. Then, parents especially have to have confidence in the capacity of the school to understand and effectively educate their children with special needs (Elkin, Van Kraayonoord , \& Jobling, 2003). Finally, knowledge and skills acquired by the children in school will endure and well controlled if they can also train them at home or outside the school environment with the help and guidance of their parents. Based on the explanation, it can be understood that the participation of parents in children's education programs with special needs is an important thing that should always be pursued. However, until now, there is no data showing that all parents of children with special needs in Indonesia have understood this, and try to fulfill it. In fact, not all parents of children with special needs recognize the importance of their involvement in the education of their children.

\subsection{Achievement Motivation}

Motivation is needed to trigger working activities, working spirit, inspiration and encouragement to employees to work better. For employees, motivation is a very important element for the achievement of organizational goals. It is a psychological process that reflects the interaction between attitudes, needs, perception and decisions that occur in a person. Psychologically, motivation arises as a factor within the person him/herself, which is called intrinsic factors and factors from the outside as called extrinsic factors. (Sadiman, 2003)stated that motivation is a series of attempts to provide certain conditions, so that a person wants and are have the will to do something and if s/he does not like it, it will try to nullify or circumvent those feelings of dislike. Motivation is a basic impulse that drives a person to behave. The impetus is in the person who moves to do something that suits his inner drive. Therefore the actions of a person based on a certain motivation have a theme according to the underlying motivation (Hamzah, 2007). Motivation is an internal and external impulse in a person to conduct behavioral changes that has the following indicators, they are (a) the desire and will to engage in the activity, (b) the drive and the need to perform the activity, (c) expectation and aspiration, (d) respect and appreciation on selves, (e) good environment, and (f) interesting activities.

According to Hamzah (2007), motivation emerges because of two factors. They are intrinsic and extrinsic factors. The emergence of intrinsic factor does not require external stimulus because it already exists within the individual itself, and is appropriate or linear with his needs. The extrinsic factors arise because of the stimulation from outside the individual. Gibson et al. in Hamzah (2007) provide his views about motivation as a concept that can be used when encouraging individuals to start and behave directly in accordance with what the leader wants. Thus, it appears that the definition of motivation concerns with the dynamic process and produce goal-oriented behavior. From idea of the parents involvement of the school in which brings the concepts of tight correlation, furthermore, one of those correlations is about academic expectation. Ritter, Michel, and Irby (1999) said that parents and students (red: disabilities, inclusion) believe that academic expectation were raised, learning more, performing to higher standards and reaping the rewards of their improved education but motivation as an inner process or psychological process that occurs in a person is strongly influenced by various factors.

In addition, there are external factors such as complete and adequate facilities and infrastructure. Motivation can also be influenced by internal factors attached to each person (innate) such as a person's education level, past experience, wishes or expectations in the future. There are some elements of the leader that can affect work motivation and wisdom that has been determined by the work requirements that need to be met by subordinates and the availability of facilities and infrastructure needed in carrying out their duties to complete the work. It can be concluded that the behavior that appears in a person or subordinates in the framework of motivation as a management concept is driven by the existence of the needs in a person. One's attitude is always oriented towards the purpose of fulfilling the desired needs.

\subsection{Learning Achievement}

Learning achievement is the result achieved by a person after making changes in learning, both at school and outside school. According to Webster's New International Dictionary, Learning Achievement is a standard test for measuring one's skills or knowledge within one or more of the lines of work or learning. Hamalik (2001) argues that learning achievement is a change in attitude and behavior after receiving a lesson or after learning something. Based on the description, it can be concluded that the learning achievement is a measure of the success of student learning activities in mastering a number of subjects during the certain period, reflected through the grades in the 
report.

\subsubsection{Factors Influencing the Learning Achievement}

Learning achievement is a measure of success obtained by students during the learning process. Success is determined by various interrelated factors. According to Slamet (1995) factors that affect student achievement include internal and external factors. Internal factor is a factor appears in an individual that undergoes a learning process such as physical factor (health and disabilities), psychological factor (intelligence, attention, interest, talent, motive, maturity, and readiness and fatigue. On the other hand, external factors the factor from the outside of the individual like family factor discuss how the parents educate, family interrelationship, home atmosphere, economic condition, family understanding, and cultural background as well, school factor like teacher's training method, curriculum, teacher-student relationship, school discipline, educational tools, school time, learning standard above rate, building condition, learning method and home assignment, and society factor such as student activities in the society, mass media, friends, and society's life pattern. Understanding the external factors is important for parents to foster students' learning achievement. By knowing the factors that influence the learning achievement of children, parents can find out the problems faced by children in learning and the influencing factors, so that parents can be actively involved in finding the source of the problem and provide the support needed by the child, in order for children to gain the best achievement in learning.

\subsection{Definition of Child with Special Needs}

The concept of Children with Special Needs (CSN) has a broader meaning than child with different abilities' meaning. CSN is a child who requires a specific service in education, different from children in general. Children are said to have special needs if there is something less or even more, in him. Alimin (2004) defined children with special needs can be understood as the children who need more attentions such as in terms of education, then the education itself must be matched with the obstacles in learning and with specific need of the individual children itself.

Furthermore, the U.S. Department of Education has categorized a wide range of special education need, in part, for the purpose of determining the scope of classroom instruction and funding requirements necessary to ensure academic achievement for all children with disabilities (Ferrel, 2012). Generally, the range of children with special needs include two categories, i.e. children with permanent special needs, namely due to certain abnormalities, and children with temporary special needs, i.e. those who experience barriers in development and learning due to environmental situations and conditions, for example children who have difficulty in adjusting themself in the society because they witnessed riots and natural disasters, or inability in reading because of teachers' mistakes, or because of cultural isolation, poverty, and so on. A temporary CSN can turn into permanent if they do not get the right intervention and in line with the learning barrier. In general, there are three factors that become barriers to learn, they are (1) environmental factors, (2) internal factors/self, (3) a combination between the two. Thus, CSN can be grouped based on the following disturbances or disorder aspects, namely (a) physical/motoric, such as cerebral palsy and polio, (b) cognitive like mental retardation, superior child (gifted), (c) language and speech, (d) hearing, (e) vision, and (f) social emotions. The children need special methods, materials, services, and equipment, in order to achieve optimal growth, since they will learn at different speeds, and also in different ways. Although they have different potentials with children in general, they should receive equal treatment and opportunities. It begins by calling them with children with special needs (CSN). In CSN, there are several important terms identified, namely:

1) Low vision, such as someone said to be low versioned if she/he still has the rest of the vision in such a way that at least they still can distinguish dark and light.

2) Weak in hearing (hard of hearing). If they lose the ability to hear ranged from 35-69 dB. They have difficulty hearing but are not hindered for him to understand other people's conversations, even using or not using tools.

3) Lack of mental (mental retardation). That is a state of weak intelligence (sub normal). Since the period of development (since birth or since childhood), which is characterized by general intelligence function that is below average, along with the reduced ability to adjust or behave adaptively.

4) Cerebral policy, namely stiffness caused by abnormalities in the brain. A child suffering from cerebral palsy does not always show stiffness, but can also show wilting or vibration or imperfect moves.

5) Emotional disturbed, is a group of children who are disturbed or obstructed by emotional development, with indication of the presence of symptoms of tension or inner conflict, showing anxiety, neurotics, or psychotic behavior.

6) Socially maladjusted is a group of children who cannot get along with the norms of community and culture, 
which applies both at home, school and community. The symptoms are as follows, at home is difficult to regulate, low learning achievement, destructive, quarrelsome, mature in social relationships, lack of learning from what is said, tend to have short attention spans due to difficulty following instructions.

7) Emotionally handicapped / Behavioral disorder, i.e. children with emotional barriers or behavioral disorders, when indicating the presence of one or more of the following five components: (1) unable to learn not because of intellectual factors, (2) health, (3) unable to make good relationships with friends and teachers, (4) behaving or feeling out of place, (5) tendering toward physical symptom, such as feeling pain or fear related to person or problem in school (Delphie, 2006).

8) Psychotic is a group of children with emotional disturbances on a heavy and very heavy level, with symptoms of experiencing disorientation of time, space, place or all three. Schizophrenia is a condition which makes a child is unable to distinguish hallucinations and reality, a common symptom of this group. To cure this group, a professional personnel is needed and they even possible to be treated in a mental hospital.

9) Attention Deficit and Hyperactive Disorder (ADHD) is an increase in motor activity up to a certain level that causes behavioral disorders that occur, at least in two places and different atmosphere. For example, explosive feelings, excessive activity, likes to make a stir, revolt, and destructive that settled

10) Down syndrome, it is a chromosomal disorder from the formation of chromosome 21 due to failure of a pair of chromosomes to separate each other when a split happened. This abnormality affects the retardation of physical and mental growth. It was first known in 1866 by Dr. John Longdon Down because of the strange features such as the relatively short height, the head is smaller, and the flat nose resembles the Mongolian.

As an effect of human rights movement, a new view emerges that all children with different abilities must be educated together with normal children in the same place. This is meant that the exceptional children should not be refused to study in the public school they want. Meanwhile, inclusive education is an educational model where children with normal and abnormal abilities can learn together in public schools. This educational system used the terminology of children with special needs or children with special education need, as a substitute for children with disabilities or extraordinary children. Several impressing ideas proposed by Balli (2016), he explained that parents were not involved enough into the school life in order to ensure the inclusion of their children within the regular education system, parents feel they should be more involved in the objectives instead of just signing the documents. Parental involvement in school takes a significant sense in terms of achieving inclusive education for their children with disabilities, who could raise the voice to protect their own right.

Other study conducted by Koster, Nakken, and Van Houten (2010) in the theme of contacts or interactions, students with special needs had fewer interactions with their classmates but more interactions with the teacher. This later finding can be viewed negatively because interactions with the teacher might be more expensive than interactions with classmate. Next, Cashin (2008) showed her research in Reynoldsburg City Schools in Ohio about parents of special needs children and its effect on special needs children's GPA. The students made academic growth throughout the school year and continued to work towards their goals, which may have led to academic success reflected in high GPAs and this growth may have been due to students' individual goals being communicated with parents at the beginning of the school year through their Individualized Education Programs (IEP's). Further, in a same sense, Vidal (2012) says that parents might have strengthened their involvement in their CWA's (Children with Autism) education and training, contributing to their children's overall improvement and achievements. This implies that every child has special needs, both permanent and non-permanent. These special needs can be divided into three; they are 1) individual needs, 2) exceptional special needs and 3) common special needs.

The model of inclusive education can be viewed as a philosophical reform, concept, and principle of education for CSN. Thus, the presence of an inclusive education model can be done as a form of renewal in view of the CSN, so that extraordinary children are no longer restricted in the setting of disability school, but are given equal rights to follow education in conjunction with normal students in public schools. It is in line with $(\mathrm{Qu}, 2015)$ that although inclusion is regarded as the common goal that all educators should aim for, it does seem that considering various practical issues, there is still a long way to go before it can be properly achieved on a large scale. This, on one hand, keeps encouraging academics and practitioners to work towards inclusion (Hasyim, 2013) in his research in the inclusive school in SMK Negeri 2 Malang that the socialization on inclusive school must be done intensively to improve the belief of parents with disabilities children and to improve the belief of the society, and the inclusive education still needs the improvement in terms of the development of teachers' quality, teaching and learning strategies and empowering participation from society(Arsidal, 2013). 


\section{Research Hypotheses}

Based on the assumptions, the hypotheses of this research are formulated into:

1) Parents' involvement significantly influences the achievement motivation of children with special needs in SMP Negeri 4 Gresik.

2) Parents' involvement significantly affects the learning achievement of children with special needs in SMP Negeri 4 Gresik.

3) Parents' involvement significantly influences the achievement motivation and learning achievement of children with special needs in SMP Negeri 4 Gresik.

\section{Methodology}

This research is designed as a survey research (data collected from the sample then the results generalized to the population) with methods and techniques of data collection as it is. The method used in this research is explanation survey method with quantitative approach through correlation and regression analysis. The analysis will be used to explain the phenomenon with quantitative prediction in testing the effect of the correlation coefficient between parents' involvement variable (X1) to achievement motivation (Y1) and learning achievement (Y2) the object of research is the students of CSN and the parents in SMP N 4, which amounted to 14 students. Data are collected using documentation and questionnaire studies. The description is given in the following figure.

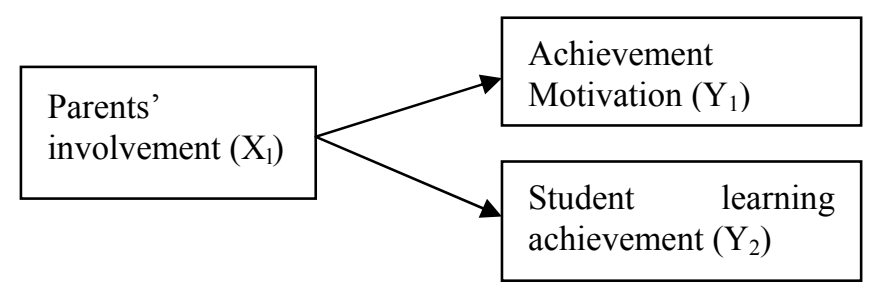

Figure 1. Research design

\subsection{Population, Sample, and Sampling Technique}

\subsubsection{Population}

According to Sugiyono (2001), population is a generalization area consisting of objects / subjects that have certain characteristics and qualities set by researchers to be studied and then drawn into conclusions. While understanding the population according to Arikunto (2003), is the overall subject of research. From this understanding, it can be concluded that the population in the study include everything that will be the subject or the object of research desired by the researcher.

Determination of the research target population and its characteristics is an important step before determining the sample. The clarity of the research problem formulated is closely related to the targeting of the population. The population in this study was students and parents of CSN at SMPN 4 which amounted to 21 people.

\subsubsection{Sample}

Research sample is part of the population taken as a source of data and can represent the population, so the type of sample taken should reflect the population. According (Sugiyono, 2001) sample is part of the number and characteristics possessed by the population. Meanwhile, according to (Riduwan, 2004) "sample is part of population". Based on preliminary observations made before the research, it was found that the number of CSN students was 14. Therefore, the entire population of CSN students in SMPN 4 Gresik is the subjects of this research. It is also called the saturated sample, so the sample in this study amounted to 14 people.

\subsubsection{Research Variables}

Based on the theories, assumptions and opinions, there are two independent variables and one dependent variable. They are parents' involvement as independent variable and achievement motivation and learning achievement as the dependent variable. The influence of parents' involvement variables on achievement motivation and learning achievement will be studied and reviewed. Based on the relationship, this influence was also studied about how big and how the characteristics are. 


\subsection{Research instrument}

\subsubsection{Validity test}

This research was conducted to measure the validity questionnaire. A questionnaire is said to be valid if the question on the questionnaire is able to reveal something that will be measured by the questionnaire. Riduwan (2002) stated that validity is a measure of indicating the reliability or validity of a measuring device. In this study, validity test is done by calculating the correlation score of each item question with the total score of a question in a variable. Correlation calculation used is correlation Warsonpoduct moment (Sugiyono, 2001) indicated by the following formula:

$R_{x y}=\frac{N \sum X Y-\left(\sum X\right)(\Sigma Y)}{\sqrt{\left.N \Sigma X^{2}-(\Sigma X)^{2}\right\}\left\{N \Sigma Y^{2}-(\Sigma Y)^{2}\right.}}$

Where,

$\mathrm{R}_{\mathrm{xy}}$ : coefficient for $\mathrm{X}$ and $\mathrm{Y}$ variables

$\mathrm{N}$ : number of respondent

$\mathrm{X}$ : number of item score from tested variables

$\mathrm{Y}$ : number of total score (all item) from tested variable

A valid question item finds a significant correlation which is indicated by a significance value less than $a=0.05$ between the items of the question measured by its validity to the total score of all the questions. A question item is invalid if its significance value exceeds $a=0.05$ or there is no significant correlation between the item of question with the total score of all the questions.

\subsubsection{Reliability Test}

Reliability test is used to measure the reliability of a questionnaire which is an indicator of the variable. A questionnaire is said to be variable if one's answer to the question is consistent or stable over time. Sugiyono (2001) stated that reliability of the instrument can be tested by analyzing the consistency of the items on the instrument with certain techniques. Reliability test on this research was done by using SPSS tool with Alpha Cronbach statistic test.

\subsection{Data Analysis Technique}

\subsubsection{Multiple Linear Regressions}

The analysis technique used in this research is multiple linear regressions. This analysis is used to examine the effect of parental involvement on achievement motivation and learning achievement with the following formula of $\mathrm{Y}=\mathrm{a}_{1+b 1} \mathrm{X}_{1}+\mathrm{b}_{2} \mathrm{X}_{1}$. Next, to perform the hypotheses testing, test approach with two kinds of variance analysis is used.

\subsubsection{F-test}

Integrity test was conducted using F-test, where trust is $95 \%$ or a $=0.05$ with the critical value: $\mathrm{Fa}$; $\mathrm{k}-1$; $\mathrm{k}(\mathrm{n}-1)$. Rejection and acceptance value of $\mathrm{H}_{\mathrm{o}}$ :

1) If $\mathrm{F}_{\mathrm{cal}}>\mathrm{F}$ tab, so $\mathrm{H}_{\mathrm{a}}$ accepted which means free variables simultaneously has significant effect on the dependent variables.

2) If $\mathrm{F}_{\mathrm{cal}}>\mathrm{F}_{\mathrm{tab}}$, then $\mathrm{H}_{\mathrm{o}}$ accepted and $\mathrm{H}_{\mathrm{a}}$ rejected which means free variables simultaneously have insignificant disturbance on the dependent variable.

Moreover, the F-test formula according to Sugiyono (2001) is elaborated into the following details.

Simple linear regression

$\mathrm{F}=\mathrm{S}^{2}{ }_{\text {reg }} / \mathrm{S}^{2}$ res

Multiple linear Regressions

$\mathrm{F}=\mathrm{R}^{2}(\mathrm{~N}-\mathrm{m}-1)$. (Sugiyono, 2001)

$\mathrm{M}\left(\mathrm{I}-\mathrm{R}^{2}\right)$

Explanation:

$\mathrm{R}^{2} \quad$ : Determination coefficient

$\mathrm{N}$ : Number of sample 
M : Number of free variable

\subsubsection{T-test}

To find out which independent variables have partial influence on dependent variable then used t-test through calculation of SPSS program to see $t$ calculate that will be compared with $t$ table. In testing this hypothesis the level of significance used was $0.05(5 \%)$ with a degree of freedom of $n-1$. The partial correlation coefficient test can be calculated by the following formula:

$\mathrm{t}_{\text {calculate }}=\frac{\sqrt{r^{2}(n-3)}}{\left(1-r^{2}\right)}$

Where:

$\mathrm{r}=$ Partial correlation

$\mathrm{n}=$ Number of sample

Criteria of Ho acceptance and rejection:

1) If $t_{c a l}>t_{t a b}$, then Ho is rejected and Ha accepted which means independent variables partially have a significant influence on the dependent variable.

2) If $t_{\text {cal }}>t_{\text {tab }}$, then Ho accepted and Ha rejected which means independent variables partially have an insignificant influence on the dependent variable.

Coefficient of determination $\left(\mathrm{R}^{2}\right)$

To know how big is the influence of independent variable on dependent variable, coefficient of determination was used via SPSS program.

\section{Research Result and Interpretation}

\subsection{Data Analysis}

Before the hypothesis test to determine the influence of independent variables (parents' involvement) to the dependent variable (achievement motivation) was conducted, validity test data in the form of validity and reliability test and prerequisite test linear regression was done first.

\subsubsection{Validity and Reliability Test}

1) Validity Test

As known before, a questionnaire instrument must be tested for its validity and reliability. The validity of this research instrument is tested by correlating each respondent's answer items with the number according to the number of questions on each variable. The correlation test used is Pearson Correlation, which can be seen in table below. The following recapitulation of the calculation results calculated ( $r$ calculation) of each item question by the amount for five variables and compared with $r$ table. If $r$ calculated $>r$ table, then the problem is valid and vice versa.

Table 1. Correlation of calculation result $\left(\mathrm{r}_{\text {calculate }}\right)$ each item of question to determine validity of each questions

\begin{tabular}{|c|c|c|c|c|}
\hline Variables & Question no. & $\begin{array}{c}\text { Correlation of calculation } \\
\left(\mathrm{r}_{\text {calculate }}\right) \\
\end{array}$ & $\mathrm{r}_{\text {table }}($ on respondents number $21 ; \mathrm{df}=19)$ & Explanation \\
\hline \multirow{4}{*}{ Parenting $\left(\mathrm{X}_{1}\right)$} & 1 & 0.723 & 0.433 & Valid \\
\hline & 2 & 0.604 & 0.433 & Valid \\
\hline & 3 & 0.703 & 0.433 & Valid \\
\hline & 4 & 0.875 & 0.433 & Valid \\
\hline \multirow{4}{*}{ Communication $\left(\mathrm{X}_{2}\right)$} & 1 & 0.804 & 0.433 & Valid \\
\hline & 2 & 0.695 & 0.433 & Valid \\
\hline & 3 & 0.695 & 0.433 & Valid \\
\hline & 4 & 0.716 & 0.433 & Valid \\
\hline
\end{tabular}




\begin{tabular}{|c|c|c|c|c|}
\hline \multirow{5}{*}{ Voluntarity $\left(\mathrm{X}_{3}\right)$} & 1 & 0.555 & 0.433 & Valid \\
\hline & 2 & 0.500 & 0.433 & Valid \\
\hline & 3 & 0.641 & 0.433 & Valid \\
\hline & 4 & 0.719 & 0.433 & Valid \\
\hline & 5 & 0.818 & 0.433 & Valid \\
\hline \multirow{5}{*}{ Home studying $\left(\mathrm{X}_{4}\right)$} & 1 & 0.682 & 0.433 & Valid \\
\hline & 2 & 0.740 & 0.433 & Valid \\
\hline & 3 & 0.639 & 0.433 & Valid \\
\hline & 4 & 0.589 & 0.433 & Valid \\
\hline & 5 & 0.562 & 0.433 & Valid \\
\hline \multirow{5}{*}{ Decision making $\left(\mathrm{X}_{5}\right)$} & 1 & 0.888 & 0.433 & Valid \\
\hline & 2 & 0.511 & 0.433 & Valid \\
\hline & 3 & 0.815 & 0.433 & Valid \\
\hline & 4 & 0.516 & 0.433 & Valid \\
\hline & 5 & 0.450 & 0.433 & Valid \\
\hline \multirow{5}{*}{ Collaborating $\left(\mathrm{X}_{6}\right)$} & 1 & 0.475 & 0.433 & Valid \\
\hline & 2 & 0.570 & 0.433 & Valid \\
\hline & 3 & 0.457 & 0.433 & Valid \\
\hline & 4 & 0.513 & 0.433 & Valid \\
\hline & 5 & 0.596 & 0.433 & Valid \\
\hline \multirow{5}{*}{ Hope (Y1.1) } & 1 & 0.510 & 0.433 & Valid \\
\hline & 2 & 0.537 & 0.433 & Valid \\
\hline & 3 & 0.753 & 0.433 & Valid \\
\hline & 4 & 0.660 & 0.433 & Valid \\
\hline & 5 & 0.644 & 0.433 & Valid \\
\hline \multirow{5}{*}{ Hope (Y1.2) } & 1 & 0.626 & 0.433 & Valid \\
\hline & 2 & 0.581 & 0.433 & Valid \\
\hline & 3 & 0.638 & 0.433 & Valid \\
\hline & 4 & 0.496 & 0.433 & Valid \\
\hline & 5 & 0.558 & 0.433 & Valid \\
\hline \multirow{4}{*}{ Perception (Y1.3) } & 1 & 0.758 & 0.433 & Valid \\
\hline & 2 & 0.588 & 0.433 & Valid \\
\hline & 3 & 0.694 & 0.433 & Valid \\
\hline & 4 & 0.817 & 0.433 & Valid \\
\hline \multirow{2}{*}{ Need (Y1.4) } & 1 & 0.714 & 0.433 & Valid \\
\hline & 2 & 0.667 & 0.433 & Valid \\
\hline \multirow{3}{*}{ Feedback (Y1.5) } & 1 & 0.671 & 0.433 & Valid \\
\hline & 2 & 0.735 & 0.433 & Valid \\
\hline & 3 & 0.716 & 0.433 & Valid \\
\hline \multirow{3}{*}{ Success consideration (Y1.6) } & 1 & 0.546 & 0.433 & Valid \\
\hline & 2 & 0.673 & 0.433 & Valid \\
\hline & 3 & 0.940 & 0.433 & Valid \\
\hline \multirow{2}{*}{ Menyatudengantugas (Y1.7) } & 1 & 0.806 & 0.433 & Valid \\
\hline & 2 & 0.792 & 0.433 & Valid \\
\hline
\end{tabular}

Source: Primary data processed in 2014.

Based on the instrument, five independent variables and one dependent variable have greater value of $r_{\text {calculate }}$ than $\mathrm{r}_{\text {table }}\left(\mathrm{r}_{\text {calculate }}>\mathrm{r}_{\text {table }}\right)$ or greater than 0.433 , at $\mathrm{df}=19$, so it can be concluded that all questions in the instrument of the study are valid and feasible to be used to retrieve research data.

2) Reliability Test

Test reliability with Cronbach Alpha from SPSS program is shown in the following table. Here is a recapitulation of the results of the intended reliability test. 
Table 2. Cronbach alpha test for reliability

\begin{tabular}{lcccc}
\hline Variables & No. of question & Cronbach Alpha Minimum & Cronbach Alpha Calculate & Explanation \\
\hline Variable $\mathrm{X}_{1}$ & 4 & 0.6 & 0.7859 & Reliable \\
Variable $\mathrm{X}_{2}$ & 4 & 0.6 & 0.7880 & Reliable \\
Variable $\mathrm{X}_{3}$ & 5 & 0.6 & 0.7577 & Reliable \\
Variable $\mathrm{X}_{4}$ & 5 & 0.6 & 0.7547 & Reliable \\
Variable $\mathrm{X}_{5}$ & 5 & 0.6 & 0.7482 & Reliable \\
Variable $\mathrm{X}_{6}$ & 5 & 0.6 & 0.6770 & Reliable \\
Variable $\mathrm{Y}_{1.1}$ & 5 & 0.6 & 0.7443 & Reliable \\
Variable $\mathrm{Y}_{1.2}$ & 5 & 0.6 & 0.7160 & Reliable \\
Variable $\mathrm{Y}_{1.3}$ & 4 & 0.6 & 0.7645 & Reliable \\
Variable $\mathrm{Y}_{1.4}$ & 2 & 0.6 & 0.7319 & Reliable \\
Variable $\mathrm{Y}_{1.5}$ & 3 & 0.6 & 0.7732 & Reliable \\
Variable $\mathrm{Y}_{1.6}$ & 3 & 0.6 & 0.7945 & Reliable \\
Variable $\mathrm{Y}_{1.7}$ & 2 & 0.6 & 0.8314 & Reliable \\
\hline
\end{tabular}

Source: Primary data processed in 2014.

Based on the above instrument, it can be seen that for five independent variables and one dependent variable the Cronbach Alpha value calculate $\left(\alpha_{\text {calculate }}\right)$ is more than the minimum limit of Cronbach Alpha value of 0.6 or greater than 0.6, so it can be concluded that the research instrument can be trusted Or Reliable. Based on the results of the above test, it can be concluded that the research instrument is valid and reliable, so it can be used to perform the next test.

\subsubsection{Classic Assumption Test (Equation 1)}

\section{1) Multicollinearity Test}

It has been explained that to determine the existence of multicollinearity, the researchers looked at the value of variance inflation factor (VIF). The commonly used VIF value is a tolerance value of at least $0.10(10 \%)$ or equal to VIF value below 10. If tolerance> $10 \%$ and VIF value in each independent variable is not more than 10 , it is concluded that there is no multicollinearity Between free variables in the regression model and vice versa. The test results show the VIF value on the free variable (parental involvement) is 1,000. The test results show VIF value at free variable not more than 10 , thus can be said that there is no multicolinearity between the independent variable so that regression model is feasible to use.

\section{2) Heteroscedastisity Test}

This test indicator is implemented by looking at the Scatterplot chart. If the points spread randomly and spread over and below the number 0 on the $\mathrm{Y}$ axis, there is no heteroscedasticity.

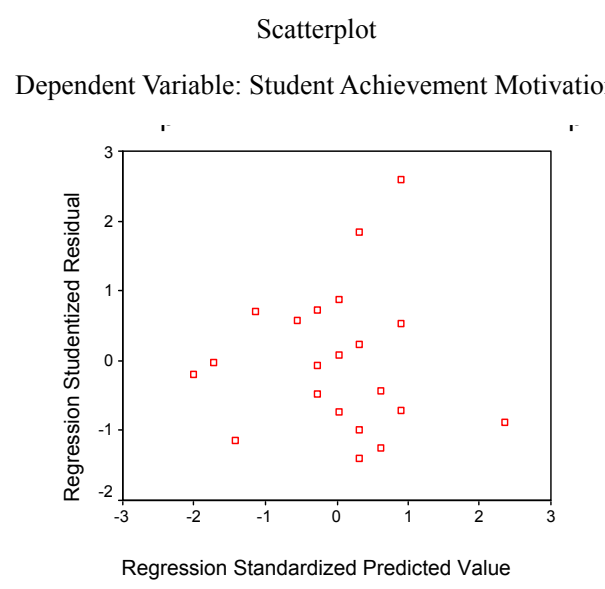

Figure 2. Scatterplot graph (Source: Primary data processed using SPSS, 2014)

From the scatterplot chart above, it is seen that the point spreads randomly and spreads above or below the number 
0 on the $\mathrm{Y}$ axis, so it can be concluded that there is no heteroscedasticity in the regression model. Thus, the regression model is appropriate to predict the achievement motivation of the students based on the input of independent variables, namely parents' involvement.

\section{3) Normality Test}

To know the treatment whether the distribution is normal or not, the line describes the actual data within the diagonal line. If the data spreads around its diagonal line and follows the direction of its diagonal line or histogram graph, then this shows a normal distribution pattern. If the data is far from the diagonal line and or does not follow the direction of the diagonal line or the histogram graph then shows the abnormal distribution pattern. Normality test results as shown in the following figure.

\section{Normal P-P Plot of Regression Standardized Residual}

Dependent Variable: Student Achievement Motivation

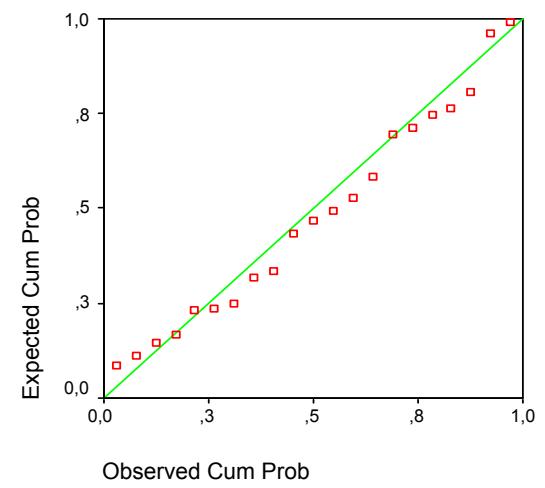

Figure 3. Normality Graph (Source: Primary data processed using SPSS, 2014)

Based on test result in regression model, dependent variable and independent variable have normal distribution. This can be seen in the picture above if the data line follows the diagonal line, the data spreads around the diagonal line and follows the direction of the diagonal line or the histogram graph so it can be said the distribution pattern is normal. Based on the results of the classic assumption test described above, it is appropriate to use for subsequent regression test.

\subsubsection{Linear Regression Test (Equation 1)}

This study uses linear regression analysis. Linear Regression Test (1) is applied to know the magnitude of influence between independent variable of parents' involvement to dependent variable of achievement motivation. Meanwhile, the multiple linear regression test results using SPSS for Windows program shown in the table below.

Table 3. Linear Regression Test

\begin{tabular}{|c|c|c|c|c|c|c|c|c|c|c|}
\hline \multicolumn{11}{|c|}{ Coefficients $^{\mathrm{a}}$} \\
\hline \multirow[t]{2}{*}{ Model } & \multicolumn{2}{|c|}{$\begin{array}{l}\text { Unstandardized } \\
\text { Coefficients }\end{array}$} & \multirow{2}{*}{$\begin{array}{c}\begin{array}{c}\text { Standardized } \\
\text { Coefficients }\end{array} \\
\text { Beta }\end{array}$} & \multirow[t]{2}{*}{$\mathrm{t}$} & \multirow[t]{2}{*}{ Sig. } & \multicolumn{3}{|c|}{ Correlations } & \multicolumn{2}{|c|}{$\begin{array}{l}\text { Collinearity } \\
\text { Statistics }\end{array}$} \\
\hline & B & Std. Error & & & & Zero-order & Partial & Part & Tolerance & VIF \\
\hline 1 (Constant) & 11.025 & 14.367 & & .767 & .452 & & & & & \\
\hline $\begin{array}{c}\text { Parents' } \\
\text { Involvement }\end{array}$ & .630 & .165 & .658 & 3.813 & .001 & .658 & .658 & .658 & 1.000 & 1.000 \\
\hline
\end{tabular}

a. Dependent Variable: Student Achievement Motivation (Source: Primary data processed using SPSS, 2014)

Next, the coefficient result of the test is put into the regression formula.

The regression equation is as follows:

$\mathrm{Y}=\mathrm{a}+\mathrm{bx}+\mathrm{e}$ 
$\mathrm{Y}=11.025+0.658 \mathrm{x}+\mathrm{e}$

1) The constant of 11,025 states that if the independent variable is considered constant, then the achievement motivation is 11.658 .

2) Regression coefficient of the parents' involvement of 0.658 states that any increase in parental involvement by 1 point will increase the motivation of achievement of 0.658 points. If it is multiplied by 1000 , the description becomes significantly increase parents' involvement of 1000 points, then, it will also increase motivation achievement which is equal to 658 point.

Based on the equation above, which shows the magnitude of the effect of parental involvement on achievement motivation, it can be said that parental involvement partially gives a significant influence on achievement motivation.

\subsubsection{Hypotheses Test (Equation 1)}

1) T-test

T-statistic test showed how far independent variable confirms the dependent variation. If the Ho is accepted if $b i=$ 0 , means that there is no influence but Ho is rejected if $b i \neq 0$, means that there is influence

The above table indicates the result of $t$-test through regression analysis from statistical computation. The t-test shows that the $\mathrm{t}_{\text {calculate }}$ value for the parent involvement variable $(\mathrm{X})$ of 3.813, the number is compared to the $\mathrm{t}_{\text {table }}$ then $t_{\text {calculate }}>t_{\text {table }}$ or $3.813>2.093$ at $\mathrm{df}=19$ (as Table in Appendix Critical Values for Distribution). The t-test results when depicted in the test acceptance curve are shown as follows.

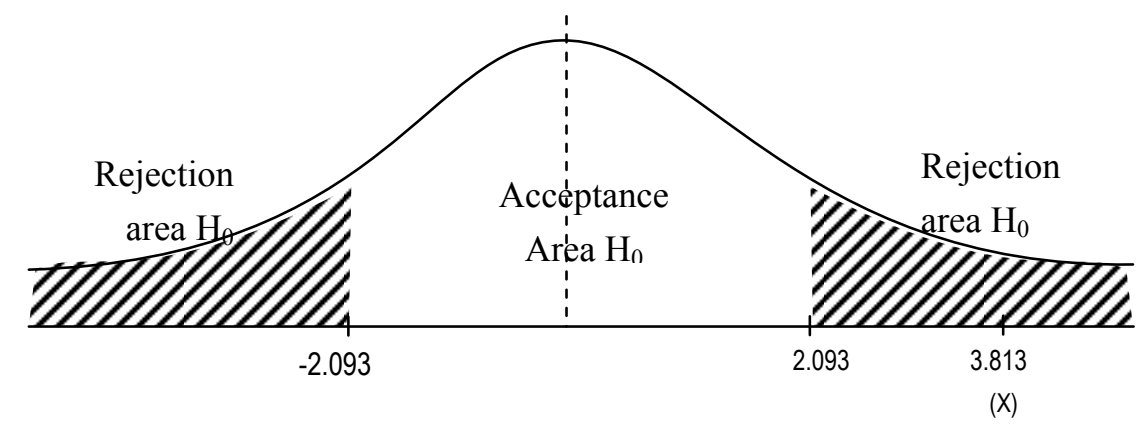

Figure 4. T-test area of acceptance and rejection (Source: Primary data processed using SPSS, 2014)

Based on the above test results, it can be seen that $t$ calculate for parental involvement variables (X), is greater than $t$ table and positive value. The t-test results are depicted in the acceptance or rejection graph of the T-Test as the figure shows that the t-test result for the independent variable is in the Ho Rejection Area. This means that the hypothesis states that there is influence of parent's involvement on achievement motivation accepted. In other words there is a positive influence of parental involvement on achievement motivation. Test showed a standard coefficient. If the Ho: $b i=0$ is rejected, and if Ho: $b i \neq 0$ is accepted. It means that the hypothesis location about variable of involvement effect is similar to zero.

2) F-test

The F-test shows whether all the independent variables included in the model have a mutual influence on the dependent variable. The null hypothesis (Ho) to be tested is whether all parameters in the model are zero, or:

Ho accepted if $\mathrm{b} 1=\mathrm{b} 2=\ldots .=\mathrm{Bk}=0$, meaning that there is no effect simultaneously (together)

Ho is rejected if $\mathrm{b} 1=\mathrm{b} 2=\ldots .=\mathrm{Bk} \neq 0$, meaning there is influence simultaneously (together)

Because in this study the free variable amounted to only one then the result of Test $\mathrm{F}$ applies only to one variable. SPSS for Windows output results in simultaneous testing as shown below. 
Table 4. F-test (Simultan)

\begin{tabular}{cccccc}
\hline \multicolumn{7}{c}{ ANOVA } \\
\hline Model & Sum of Square & df & Mean Square & F & Sig. \\
\hline 1 Regression & 93.547 & 1 & 93.547 & & \\
Residual & 122.262 & 19 & 6.435 & 14.538 & $.001^{\mathrm{a}}$ \\
Total & 215.810 & 20 & & & \\
\hline
\end{tabular}

a. Predictors: (Constant), Parents' involvement

b. Dependent Variable: Student achievement motivation

Source: Primary data processed using SPSS, 2014

From the calculation result using SPSS, it is found that the F-calculate is $14.538>$ F-table of 4.38 at $\mathrm{df}=19$ (as in Appendix Critical Values for the F Distribution $(\alpha=0.05)$, besides the probability of test result on it is 0.001 far below 0.05 , then Ho is rejected thus proved that parental involvement influences the achievement motivation. The following graph shows the result of F-test if described in the receipt test curve is as follows.

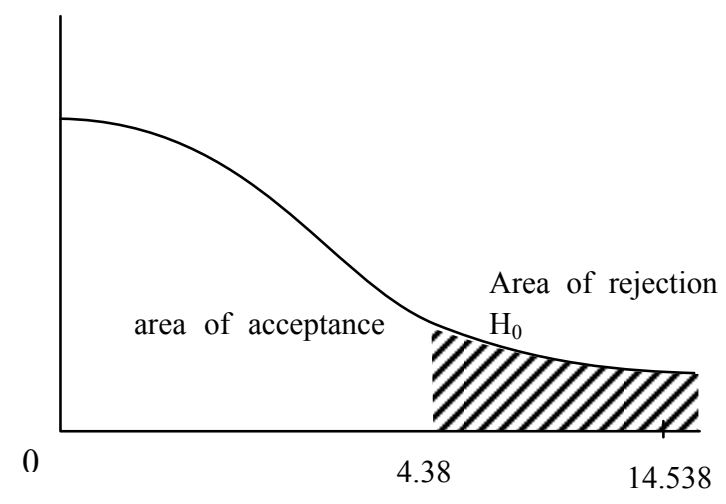

Figure 5. Area of acceptance and rejection in F-test (Source: Primary data processed, 2014)

The figure shows that the F-calculate value of 14.538 is in the rejection area of Ho, meaning the null hypothesis is rejected and the alternative hypothesis is accepted so that the free variable (parental involvement) included in the model has an influence on the dependent variable that is the achievement motivation. Koefisien Determinasi $\left(\mathrm{R}^{2}\right)$.

Coefficient of determination (R2) serves to measure how far the ability of the model in explaining the variation of dependent variable is. It can be seen in the table below.

Table 5. Determination coefficient $\left(\mathrm{R}^{2}\right)$

\begin{tabular}{cccccc}
\hline \multicolumn{5}{c}{ Model Summary $^{\mathrm{b}}$} \\
\hline Model & $\mathrm{R}$ & R Square & Adjusted R Square & Std. Error of the Estimate & Durbin-W atson \\
\hline 1 & $.658^{\mathrm{a}}$ & .433 & .404 & 2.53670 & 1.976 \\
\hline
\end{tabular}

a. Predictors: (Constant), Parents Involvement.

b. Dependent Variable: Student achievement motivation.

Source: Primary data processed using SPSS, 2014.

Test results as shown in the table above reveals the coefficient of determination (R2) of 0.433 . This means that $43.3 \%$ of achievement motivation variations can be explained by variations of independent variables (parental involvement). While the rest $(100 \%-43.3 \%=56.7 \%)$ is explained by other factors outside of this study. In addition, $\mathrm{R}$ value of 0.658 and the value of Adjusted R Square of 0.404 indicates that if parent's involvement is in good condition, by maintaining the indicators of each variable attached in the questionnaire, then the variable will be able to give effect of $65.8 \%$ and if no effort In increasing the variable parent involvement or less attention then 
only able to give influence of $40.4 \%$ only on achievement motivation. These figures show the ability of parental involvement variables to explain the dependent variable of achievement motivation.

\subsubsection{Classics Assumption Test (Equation 2)}

\section{1) Multicollinearity Test}

It is explained that to determine whether or not there is multicollinearity, the researchers looked at the value of variance inflation factor (VIF). The commonly used VIF value is a tolerance value of at least $0.10(10 \%)$ or equal to VIF value below 10. If tolerance> $10 \%$ and VIF value in each independent variable is not more than 10 , it is concluded that there is no multicollinearity Between independent variables in the regression model and vice versa. The test results show the VIF value on the free variable (parental involvement) is 1,000. The result of the test shows that VIF value on independent variable is not more than 10 , so it can be said that there is no multicolinearity between independent variables so that this regression model is feasible to be used.

\section{2) Heteroscedasticity Test}

This test indicator is by looking at the Scatterplot chart. If the points spread randomly and spread over and below the number 0 on the $\mathrm{Y}$ axis, no heteroscedasticity occurs.

Scatterplot

Dependept variable: Learning Achievement

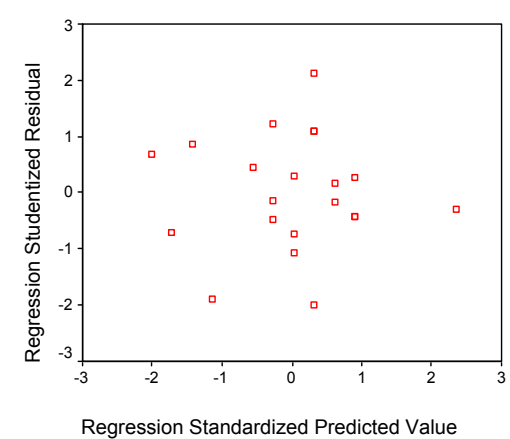

Figure 6. Scatterplot Graph (Source: Primary data processed using SPSS, 2014)

From the scatterplot chart above, it can be seen that the spreading point is random distributed above and below the number 0 on the $\mathrm{Y}$ axis, it can be concluded that there is no heteroscedasticity in the regression model so that the regression model is appropriate to predict the student's learning achievement based on independent variable input that is parent's involvement.

3) Normality Test

It has been explained that in order to know the treatment of normal distribution, it is necessary to see whether the line representing the real data will follow its diagonal line or not. If the data spreads around its diagonal line and follows the direction of its diagonal line or histogram graph then it shows the normal distribution pattern. If the data is far from the diagonal line and or does not follow the direction of the diagonal line or the histogram graph then shows the abnormal distribution pattern. Normality test results as shown in the following figure. 
Normal P-P Plot Regression Standardized Residual

Dependent variable: Learning achievement

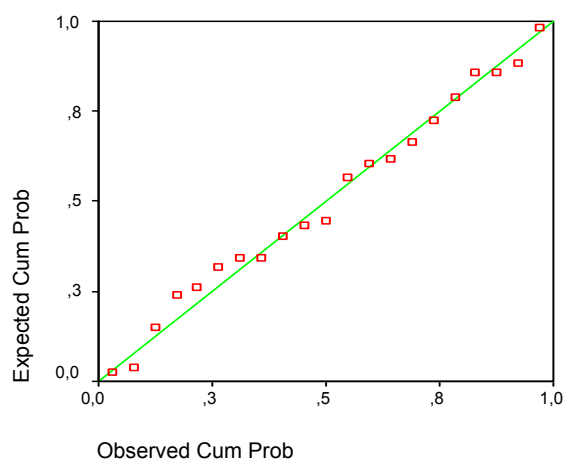

Figure 7. Normality graph (Source: Primary data processed using SPSS, 2014)

Based on the test results in the regression model, the dependent variable and the independent variable have a normal distribution, it can be seen in the picture above which shows that the data line follows the diagonal line, the data spreads around the diagonal line and follows the direction of the diagonal line or histogram graph, so it can be said distribution pattern is normal. Based on the results of the classic assumption test described above, it is appropriate to use for subsequent regression test.

\subsubsection{Linear Regression Test (Equation 2)}

This study uses linear regression analysis. Linear Regression Test (2) to know the effect of free variable involvement of parents to the dependent variable that is learning achievement.

Multiple linear regression test results using SPSS for Windows program as the table below.

Table 6. Linear regression test

\begin{tabular}{|c|c|c|c|c|c|c|c|c|c|c|}
\hline \multicolumn{11}{|c|}{ Coefficients $^{\mathrm{a}}$} \\
\hline \multirow[t]{2}{*}{ Model } & \multicolumn{2}{|c|}{$\begin{array}{c}\text { Unstandardized } \\
\text { Coefficients }\end{array}$} & \multirow{2}{*}{$\begin{array}{c}\text { Standardized } \\
\text { Coefficients } \\
\text { Beta } \\
\end{array}$} & \multirow[t]{2}{*}{$\mathrm{t}$} & \multirow[t]{2}{*}{ Sig. } & \multicolumn{3}{|c|}{ Correlations } & \multicolumn{2}{|c|}{$\begin{array}{c}\text { Collinearity } \\
\text { Statistics } \\
\end{array}$} \\
\hline & $\mathrm{B}$ & Std. Error & & & & Zero-order & Partial & Part & Tolerance & VIF \\
\hline 1 (Constant) & 23.204 & 16.909 & & 1.372 & .186 & & & & & \\
\hline $\begin{array}{c}\text { Parents } \\
\text { Involvement }\end{array}$ & .700 & .194 & .637 & 3.601 & .002 & .637 & .637 & .637 & 1.000 & 1.000 \\
\hline
\end{tabular}

a. Dependent variable: child learning achievement (Source: Primary data processed using SPSS, 2014)

After that, the coefficient of the test is included in the regression with the following formula. The regression equation is as follows:

$\mathrm{Y}=\mathrm{a}+\mathrm{bx}+\mathrm{e}$

$\mathrm{Y}=23.204+0.637 \mathrm{x}+\mathrm{e}$

1) The constant of 23,204 states that if the independent variable is considered to be constant, then the learning achievement of the child is 23.204 .

2) Regression coefficient parent involvement of 0.637 states that any increase in parental involvement by 1 point then it shall improve the learning achievement of children by 0.637 points. If multiplied by 1000 , the description becomes every increase of parent involvement of 1000 point hence will increase student achievement equal to 637 point.

Based on the above equation, it can be said that parental involvement partially gives a significant influence on the learning achievement of children.

\subsubsection{Hypothesis Test (Equation 2)}

1) T-test 
The statistical t-test $t$ shows how far the influence of one independent variable individually in explaining the dependent variation. The zero hypotheses (Ho) to be tested is whether a parameter (bi) is equal to zero or not. If Ho is received if $b i=0$, meaning no effect and if Ho is rejected if $b i \neq 0$, meaning there is an influence. This can be seen in the table above. It is the result of t-test through regression analysis with the help of SPSS for Windows program. The t-test shows the value for the parent involvement variable (X) of 3.601, the number is compared with the table then $t_{\text {calculate }}>t_{\text {table }}$ or $3.601>2.093$ at $d f=19$ (as in the Table in Appendix Critical Values for Distribution).The t-test result can be depicted from the following curve.

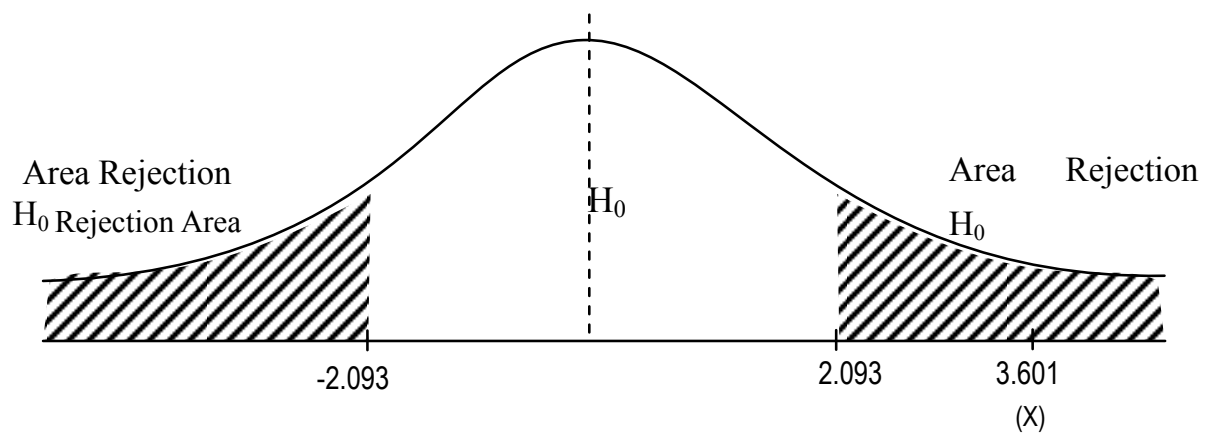

Figure 8. Acceptance and rejection area in t-test (Source: Primary data processed using SPSS, 2014)

Based on the test result above, $t_{\text {calculate }}$ for parent involvement variable $(\mathrm{X})$ is bigger than $\mathrm{t}_{\text {table }}$ and it has a positive value. The t-test results are depicted in the acceptance or rejection graph of t-test as shown in the picture. The result of $t$ test for the independent variable is in the rejection area of Ho. It means that the hypothesis stating the influence of parent involvement on the learning achievement of the child is accepted. In other words, there is a positive influence of parental involvement on children's learning achievement.

The test result shows the coefficient standard means. If $\mathrm{Ho}: \mathrm{bi}=0$ rejected, and if $\mathrm{Ho}: \mathrm{bi} \neq 0$ received. It means that the hypothesis about the influence of variables involvement of parents on learning achievement of children is accepted (bi not equal to 0 ).

2) F-test

F-test shows the independent variables included in the model have a simultaneous effect on the dependent variable. The null hypothesis (Ho) to be tested is whether all parameters in the model are zero, or Ho is accepted if b1 =b2 and $\mathrm{Bk}=0$. It means that there is no simultaneous effect occurs. The reason, the number of independent variables in this study only one, then the results of Test F applies only to one variable. SPSS for Windows output results in simultaneous testing as shown below.

Table 7. F-test (Simultan)

\begin{tabular}{cccccc}
\hline \multicolumn{7}{c}{ ANOVA $^{\mathrm{b}}$} \\
\hline Model & Sum of Square & df & Mean Square & F & Sig. \\
\hline 1 Regression & 115.587 & 1 & 115.587 & & \\
Residual & 169.366 & 19 & 8.914 & 12.967 & $.002^{\mathrm{a}}$ \\
Total & 284.952 & 20 & & & \\
\hline
\end{tabular}

a. Predictors: (Constant), parents' involvement.

b. Dependent variable: Children learning achievement.

Source: Primary data processed using SPSS, 2014.

The calculation using SPSS got $\mathrm{F}_{\text {calculate }}$ as $12.967>\mathrm{F}_{\text {table }}$ as $4.38 \mathrm{in} \mathrm{df}=19$ (as it was depicted in the following table of the Critical Values for the F Distribution $(\alpha=0.05)$. Besides, the probability of test result is higher, that is 0.002 , far less than 0.05 . Therefore, Ho is rejected, and so it is proven that parents' involvement affect child learning achievement. 
The result of the F-test can be seen on this test acceptance graph.

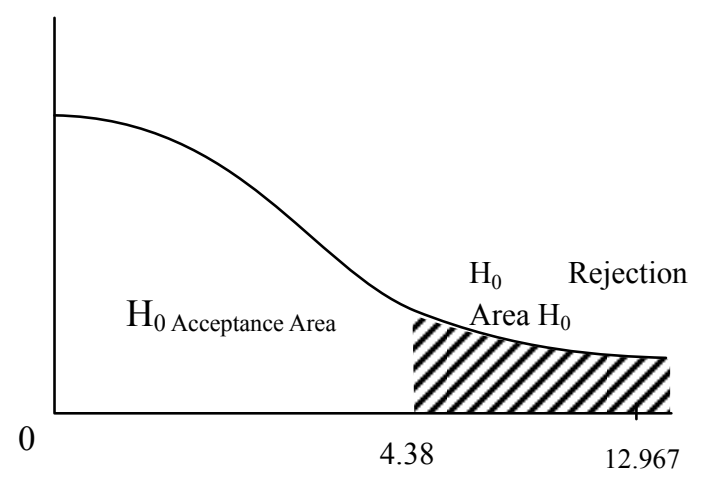

Figure 9. Acceptance and Rejection of F-test (Source: Primary data processed, 2014)

The picture shows that the $\mathrm{F}_{\text {calculate }}$ value is 14.538 is in the rejection area of Ho, meaning the zero hypothesis is rejected and the alternative hypothesis is accepted so that the independent variable (parental involvement) included in the model has an influence on the dependent variable that is the learning achievement of the child.

3) Determination Coefficient $\left(R^{2}\right)$

Coefficient of determination $\left(\mathrm{R}^{2}\right)$ serves to measure how far the ability of the model in explaining the variation of dependent variable can be seen test results in the table below.

Tabel 8. Coefficient of determination (R2)

\begin{tabular}{cccccc}
\hline \multicolumn{5}{c}{ Model Summary $^{\mathrm{b}}$} \\
\hline Model & $\mathrm{R}$ & R Square & Adjusted R Square & Std. Error of the Estimate & Durbin-W atson \\
\hline 1 & $.637^{\mathrm{a}}$ & 406 & .374 & 2.98563 & 2.253 \\
\hline
\end{tabular}

a. Predictors: (Constant), parents involvement.

b. Dependent variable: Child learning achievement.

Source: Primary data processed using SPSS, 2014

The test results, as displayed in the table above, shows the coefficient of determination $\left(R^{2}\right)$ of 0.406 , which means $40.6 \%$ variation in child learning achievement can be explained by variations of the independent variables, i.e. parents' involvement. The rest $(100 \%-40.6 \%=59.4 \%)$ is explained by other factors outside this research. $\mathrm{R}$ value of 0.637 and Adjusted R Square in the value of 0.374 indicates that if parent involvement is in good condition by maintaining the indicators of each variable attached in the questionnaire. Thus, the variable will be able to give influence of $63.7 \%$ and if there is no effort in increasing the parent involvement variable or giving insufficient attention then the given effect would only reach as much as $37,4 \%$ only on learning achievement of the child. These numbers show the ability of parents' involvement variables to explain the dependent variables, i.e. of learning achievement on children.

\subsection{Conclusion}

The above results show that how big is the magnitude of the influence of parental involvement on students' achievement and motivation. This is because motivation can arise either from internal or external of the students.Motivation is a dynamic process and it produces goal-oriented behavior. Motivation as an inner process or psychological process that occurs in an individual is strongly influenced by various factors. Consequently, the involvement of parents is something that should be developed in order to enhance children's motivation. The results also show the magnitude of the influence of parental involvement on learning achievement of children. There is no different argument from the explanation above for the realistic role of parents in facilitating and enhancing chidren's learning achievement. Finally, it can be concluded that there is a significant effect of parents involvement on achievement motivation of the children with special needs in SMP Negeri 4 Gresik and there is 
also a significant effect of parents' involvement on learning achievement of the children with special needs in SMP Negeri 4 Gresik.

\section{References}

Alimin, Z. (2004). Anak Berkebutuhan Khusus. Bandung: Jurusan PLB-FIB UPI.

Arikunto, S. (2003). Prosedur Penelitian Pendidikan. Jakarta: PT. BimaAksara.

Arsidal, D. (2013). Pelaksanaan Pembelajaran Siswa Berkebutuhan Khusus di SMK Negeri 4 Padang. Journal of Pedagogia, XIII(1).

Balli, D. (2016). Importance of Parental Involvement to Meet the Special Needs of their Children with Disabilities in Regular School. Academic Journal of Interdisciplinary Studies, 5(1). https://doi.org/10.5901/ajis.2016.v5n1p147

Buchori, M. (2006). Pendidikan Gagal Tanpa Partisipasi Orang Tua. Basis: Menembus Fakta, 55(07), 13.

Cashin, E. S. (Producer). (2008). Increased Communication with Parents of Special Needs Children and its Effect on Special Needs Children's GPA. Retrieved from http://www.otterbein.edu/Files/pdf/Education/ JTIR/VolumeVI/Cashin.pdf

Clough, P., \& Nutbrown, C. (2004). Special Educational Needs and InclusionL: Multiple Perspective of Preschool Educatores in the UK. Journal of Early Childhood Research, 2(2), 191-211. https://doi.org/10.1177/1476718X04043015

Delphie. (2006). Pembelajaran Anak Berkebutuhan Khusus. Bandung: PT. RefikaAditama.

Elkin, J., Van Kraayonoord E. C., \& Jobling, A. (2003). Parents' Attitudes to Inclusion of their Children with Special Need. Journal of Research in Special Educational Needs, 3(2), 122-129. https://doi.org/10.1111/1471-3802.00005

Faradina, N. (2016). Penerimaan Diripada Orang Tua yang Memiliki Anak Berkebutuhan Khusus. Ejournal Psikologi, 4(4), 386-396.

Ferrel, J. (2012). Family Engagement and Chidren with Disabilities: A Resource Guide for Educators and Parents. Cambridge: Harvard.

Hadjiyiannakou, A., Ioannou, C., \& Tzoigkouros, C. (2007). Parents of Disabled Chidren: The Educational Ssytem and the Everyday Challenges. International Journal about Parents in Education, 1(0).

Hamalik, O. (2001). Proses Belajar Mengajar. Jakarta: PT. BumiAksara.

Hamzah, R. (2007). Kepemimpinan Strategi mengefektifkan Organisasi. Jakarta: PT. Gramedia.

Handoyo. (2001). Peranan Ibu Bapak Mendidik Anak. Bandung: PT. Angkasa.

Hasyim, Y. (2013). Pendidikan Inklusif di SMK Negeri 2 Malang. Jurnal Kebijakan dan Pengembangan Pendidikan, 1(1).

Koster, M., Pijl, J. S., Nakken, H., \& Van Houten, E. (2010). Social Participation of Students with Special Needs in Regular Primary Education in the Netherland. International Journal of Disability, Development and Education, 57(1). https://doi.org/10.1080/10349120903537905

MacKichan, D. M., \& Harkins, J. M. (2013). Inclusive Education: Perceptions of Parents of Children with Special Needs of the Individual Program Planning Process. Electronic Journal of Inclusive Education, 3(1).

Mintari P, T., \& Widyarini, N. (2015). Gambaran Strategi Coping pada Orang Tua yang Memiliki Anak Berkebutuhan Khusus (ABK). Jember: Fakultas Psikologi Universitas Muhammadiyah Jember.

Murray, M. M., Handyside, M. L., Straka, A. L., \& Arton-Titus, V. T. (2013). Parents Empowerment: Connecting with Preservice Special Education Teachers. School Community Journal, 23(1).

Qu, X. (2015). Understanding Special School Provision for Children with Severe Learning Difficulties in Relation to Inclusive Education. Cambridge Open-Review Educational Research e-Journal, 1(1).

Riduwan. (2002). Skala Pengukuran Variabel Variabel Penelitian. Bandung: PT. Alfa Beta.

Riduwan. (2004). Metode dan Teknik Menyusun Tesis. Bandung: PT. Alfa Beta.

Ritter, C. L., Michel, C. S., \& Irby, B. (1999). Concerning Inclusion: Perceptions of Middle School Students, Their Parents, and Teachers. Journal of Rural Special Education Quartely, 18(2), 10-16. https://doi.org/10.1177/875687059901800203 
Rodriguez, R. J., Blatz, E. T., \& Elbaum, B. (2014). Parents' Views of Schools' Involvement Efforts. Exceptional Children Journal, 81(1), 79-95. https://doi.org/10.1177/0014402914532232

Sadiman, A. (2003). Media Pendidikan: Pengertian, Pengembangan, danPemanfaatannya. Jakarta: Pustekom Diknas dan PT. Raja Grafindo Perkasa.

Slamet. (1995). Belajar \& Faktor-Faktor Yang Mempengaruhinya. Jakarta: PT. Rineka Cipta.

Sugiyono. (2001). Metode Penelitian Administrasi. Bandung: PT. Alfa Beta.

Vidal, L.-S. (2012). Intellectual, Academic, and Psychosocial Self-Care Achievementsamong Children with Autism. Education Quartely, 70(1), 26-40.

Wang, L. H. (2009). Should All Students with Special Educational Needs (SEN) Be Included in Mainstream Education Provision?-A Critical Analysis. International Education Studies, 2(4), 154-161. https://doi.org/10.5539/ies.v2n4p154

Whitning, M. (2012). Impact, Meaning and Need for Help and Support: The Experience of Parents Caring for Children with Disabilities, Life-limiting/Life-Threatening Illness or Technology Dependence. Journal of Child Health Care, 17(1), 92-108. https://doi.org/10.1177/1367493512447089

\section{Copyrights}

Copyright for this article is retained by the author(s), with first publication rights granted to the journal.

This is an open-access article distributed under the terms and conditions of the Creative Commons Attribution license (http://creativecommons.org/licenses/by/4.0/). 